\title{
Exploring the range of retention issues for seafarers in global shipping: opportunities for further research
}

\author{
Livingstone Divine Caesar • Stephen Cahoon • Jiangang Fei
}

Received: 12 August 2014 / Accepted: 16 January 2015 / Published online: 19 February 2015

(C) World Maritime University 2015

\begin{abstract}
Discussions surrounding the global shortage of seafarers (especially ship officers) continue to evolve and have attracted the attention of a growing number of researchers and industry practitioners in recent times. There is a general consensus within the literature that ship-to-shore mobility among seafarers (including officers and unlicensed mariners) is increasing. Prolonging the number of years that seafarers spend at sea and their subsequent retention is therefore an important issue that requires further attention. This conceptual paper (which is the product of a systematic literature review on seafarers) argues that to effectively retain ship officers and cadets at sea, the range of factors negatively influencing their retention must be identified and sufficiently managed by shipping industry employers. The result from the synthesis of the reviewed literature shows that the range of retention issues that shipping industry employers need to focus on relates mostly to the following: satisfaction with job and employer, opportunities for career progression and good working conditions. The paper also examines the cluster of human resource practices and theories among industry employers and how they eventually predict the mobility of seafarers to landside jobs. Recommendations are given on how shipping industry employers may be able to alleviate the current labour crisis within the shipping industry through prudent retention strategies.
\end{abstract}

Keywords Seafarers $\cdot$ Retention · Shipping industry Ship officers

L. D. Caesar $(\bowtie) \cdot$ S. Cahoon $\cdot$ J. Fei

Australian Maritime College, Maritime Way, Launceston, TAS, Australia

e-mail: dlcaesar@amc.edu.au

S. Cahoon

e-mail: s.cahoon@amc.edu.au

J. Fei

e-mail: jfei@amc.edu.au 


\section{Introduction-the need to improve retention}

The retention of ship officers onboard vessels remains an important issue within the seafaring sector with a reported one in ten officers leaving the industry prematurely (BIMCO/ISF 2005). Pekcan et al. (2003) also suggest that less seafarers are staying at sea beyond 10 years. Those who do remain may stay until retirement, yet such a category of people is increasingly becoming rare as a result of deteriorating working conditions onboard. Considering that it takes an average of 4 years to produce junior officers and an additional 6 years to have them become senior officers (Eler et al. 2009), the statistic of many seafarers leaving within 10 years (Moreby 1975; Shiptalk 2008; Ljung 2010) is quite disturbing since most may not become masters thereby worsening the prevailing labour crisis at the higher echelon of a ship's crew complement (Caesar et al. 2013).

Figure 1 provides an overview of the various points along a seafarer's career pathway where attrition is quite evident. The first stage of exit among seafarers occurs during the period of cadetship, and this usually happens in the first 14 months due to the following factors:

- Inability to cope with the strenuous nature of life at sea

- Classroom learning difficulties; and

- Inhumane and unsupportive attitude from mentors at sea (Gekara 2008, 2009)

Also, attrition is prevalent among integrated ratings and cadets who progress to the rank of junior officers (Obando-Rojas et al., 1999). The literature (see for example, Pekcan et al. 2003; Gekara 2009; Gould 2010) suggests that all seafarers can become shipmasters, and this is also accepted globally (Gekara 2008), but this may not be the case at the organisational level as hiring and other human resource policies do not favour all seafarers in terms of career progression. People sign on to become seafarers for varying reasons that are often accompanied by different anticipated timeframes from short, medium and to long term.

Figure 1 shows that at a certain stage in the career of seafarers, there may be a convergence of termination factors which makes it difficult for them to become senior officers and hence leave to landside jobs (Cahoon et al. 2014). At this stage, the seafarer may be in their late 20 s or early 30 s, where externalities are also having an impact on voluntary turnover decisions, such as becoming married, beginning a family or being concerned about ageing parents.

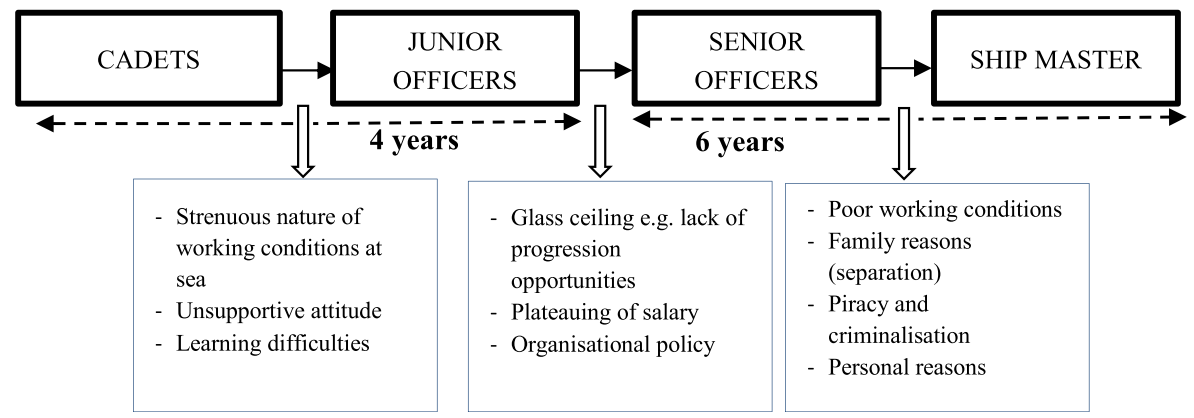

Fig. 1 Points of attrition in a seafarer's career 
In particular, the lack of career prospects features strongly among the reasons for high attrition among cadets in traditional maritime nations (Gekara 2008, 2009) as uncertainty of future employment demotivates them and deflates their morale to undergo the entire training programme. In a study of Danish seafarers and specifically officers, Haka et al. (2011) found that the major reasons for leaving seafaring are the following: spending a long time away from home and family, problems posed by cultural differences, isolation or loneliness among officers. Thus, the need to improve retention among seafarers exists, and understanding the reasons for attrition is central to finding solutions to the problem. The introductory section of this paper highlights the seafarer shortage issue. The second section provides details on the methodology used in analysing the data for the paper. In the third section, the reason for which retention of seafarers is becoming difficult is outlined. In 'Section 4' and 'Section 5', the key range of retention problems for seafarers and the strategies being used by employers to address the identified issues, respectively, are discussed. In the final section of the paper, the conclusions are presented along with recommendations on policy directions and the issues that need attention from future researchers.

\section{Methodology}

The aim of this study is to synthesise factors that significantly influence seafarer retention. Separate searches were conducted in key academic databases such as the Taylor and Francis Online Journals, JSTOR Online Journals, Elsevier Online Journals, WMU Journal of Maritime Affairs Online and International Association of Maritime Universities (IAMU) Journal Online.

Keyword search of the abstracts and titles (Bos and Tarnai 1999) of the aforementioned databases produced 108 articles. The 108 articles were reviewed for appropriateness (i.e. relating directly to shortage of ship officers and factors impacting retention) to ensure that the articles correspond with the topic (Hart 2012). This led to a reduction of the 108 articles to 68 articles. After applying a set of predefined inclusion criteria to the 68 articles, the number was reduced to 47. The inclusion criteria applied to the 68 articles and works are as follows: (i) those published from 1990, (ii) published in a peer-reviewed journal and (iii) that address factors influencing the retention of seafarers. Articles were excluded (i) if not written in English and (ii) if they did not contain original data.

The remaining 47 articles were further screened using content analysis to determine which ones should be included or excluded. Frequently used as a qualitative research technique, content analysis is also effective in reducing large sizes of data to simplify the work of social science researchers (Krippendorff 1980; Bos and Tarnai 1999; Mayring 2004; Kohlbacher 2006; Elo and Kyngäs 2008). It is also a powerful technique for assessing trends and patterns in articles (Stemler 2001). Decisions made during the content analysis for the 47 articles relate to which data to analyse, how they should be defined, population, context, boundaries for the analysis and the outcome of inferences to be made (Krippendorff 1980; Kohlbacher 2006).

As a result of conducting the content analysis (Elo and Kyngäs 2008), 19 articles were identified as having the key themes relating to seafarer retention. The next stage after identification of the 19 articles was development of the general themes using 
colour coding. Subthemes were then developed for coding of the information. Thus, the steps described by Mayring (2004) for the inductive process of content analysis were used for the analysis of data in the 19 articles. Once selected for inclusion, articles were reviewed and variables of interest identified. Attention was paid to determine if the variable had a positive or negative correlation to seafarer retention. As a final step, all identified variables were assessed for commonalities in variables related to the movement of seafarers from ships to landside jobs. This helped to identify and understand the complex range of retention issues that must be addressed to prolong the number of years that seafarers spend at sea working onboard ships before moving to landside jobs. Thus, 19 articles in total met the predefined criteria. Data on the reasons why retention of seafaring is becoming difficult and the factors that possibly predict the movement of seafarers to landside jobs was extracted from the selected articles that met the predefined criteria. Figure 2 summarises the key steps used in sampling and analysing the articles for this paper.

\section{Reasons for poor retention}

The reasons for poor retention among seafarers may equally represent the key factors identified in the literature (see for example, Mack 2007; Mitroussi 2008) as being responsible for ship officers moving to landside jobs. These reasons as elaborated by Barnett et al. (2006) include the following: a lack of opportunities for career progression at sea, the need for young officers to start or build a family, the sudden emergence of landside opportunities and poor working conditions onboard (influenced by increased workload, stress, loneliness, isolation and cultural diversities).

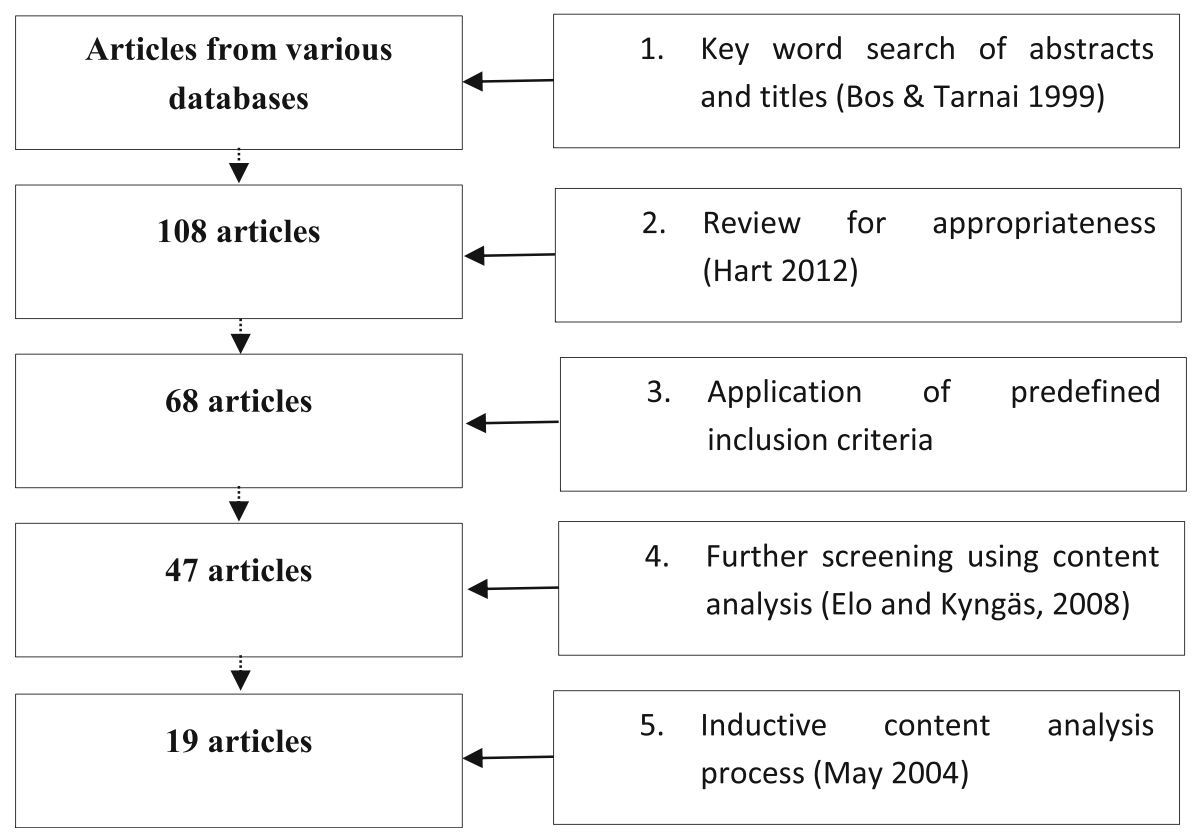

Fig. 2 Sampling and data analysis steps 


\subsection{Poor HR practices of employers}

Poor human resource practices could be one of the reasons why the retention of ship officers is becoming difficult. For instance, shipping industry employers tend to stratify their employees based on geographic origin or ethnic background, and this for some largely influences staff promotion onboard vessels with some nationalities having preeminence over others (Lane 2002; Wu 2004). Hence, for some nationalities, less opportunity to rise up the hierarchical ladder onboard to become a senior officer triggers their movement to land, or they may remain at sea yet unhappy, but the former is usually the likely outcome. As per the Herzberg employee motivation model (Herzberg et al. 1993), advancement is a key tool for retaining employees to which seafarers are no exception (Lindgren and Nilsson 2012); hence, a lack of opportunities for advancement onboard causes them to seek land-based careers.

Other pertinent issues that constitute poor human resource practices among shipping industry employers and as raised by seafarers as reasons for their leaving the industry include as follows: the ill treatment of seafarers through unfair contracts, desertion by shipowners and salary arrears (Couper 2000), insufficient shore leave, inability to contact families while at sea, highly pressurised working conditions and the additional workload onboard. Also, the lack of support from shore side staff can lead to frustrations for seafarers and their eventual movement to landside jobs. This problem is more common where the shore side staff do not have a seafaring background as they are unable to appreciate the dynamics of the job at sea (Sherar 1973). These poor human resource practices demotivate seafarers and also lead to reduced or loss of job satisfaction (Forsyth 1990; Kronberg 2011).

\subsection{Generational issues}

Another important issue that helps in understanding why the retention of seafarers is challenging is the generational gap factor that influences the progressive mobility of ship officers to landside jobs. There are differences in the level of expectations between the younger and older generations in the seafaring industry (Cahoon and Haugstetter 2008). Many in the older generation of seafarers indicate they were lured into seafaring by the desire for adventure due to the stories they heard from their predecessors about foreign lands (Mack 2007). However, the emergence of skeletal ship crew onboard, cheaper means of transportation and increased workload, means that seafaring has ceased to be a career of adventure (Dimitrova and Blanpain 2010). Hence, the adventure element has transformed into a subjective phenomenon that shipowners cannot rely upon to retain crew (Horck 2010). Thus, the era where seafaring was viewed as a lifetime profession has elapsed. The expectations of the younger generation of ship officers differ from those of their predecessors; hence, the need for industry employers to critically scrutinise these differences and address them is necessary to reduce the early exit to land.

\subsection{Increased demand from landside}

Retaining ship officers at sea is quite difficult when one considers the increase in demand for their operational skills among landside employers. There are many shore- 
based career positions that ship officers occupy as they move from the onshore to the offshore sector of the maritime industry (Barnett et al. 2006). The increased demand for the expertise of ship officers and other categories of seafarers among landside employers is given further impetus by the relatively high remuneration rates being offered for the positions. For instance, Wild (2012) discovered that high salary is often offered by oil companies to attract people with seafaring experience for onshore jobs. This serves as an additional source of competition for the already limited pool of officers working onboard ocean-going ships.

\subsection{Peculiar nature of seafaring career}

The peculiar nature of working in the shipping industry constitutes one of the key reasons why it is difficult to retain seafarers to work onboard ships (Thomas et al. 2003; De Silva et al. 2011). All seafarers essentially share similar reasons for their departure to land (Barnett et al. 2006), with separation from partner and family cited as the common reason (Rochdale 1970; Barnett et al. 2006). Hence, many seafarers having families become less satisfied with their jobs at sea, and this significantly influences their decision to reduce years spent at sea (Forsyth 1990). According to Iversen (2011), separation increases loneliness among seafarers and when coupled with fatigue and stress (Parker et al. 1997) creates mental depression - a cause of suicide among seafarers. Early researchers (Hill 1972; Moreby 1975; Forsyth and Gramling 1990) acknowledge that separation creates disruption in family and marital life, and this is a cause of high attrition among seafarers (Oldenburg et al. 2009; Haka et al. 2011). Separation in itself is stressful for both seafarers and their partners, leading to the loss of a critical psychogenic protective factor onboard (Oldenburg and Jensen 2012). Hence, separation does affect not only the partner at sea but also the one at home (Thomas et al. 2003). According to Jeżewska and Iversen (2012), the impact created by separation of seafarers from their families is multidimensional, and its severity is influenced by several factors (for example, spouse, children, working conditions, contact with family).

Thus, the uniqueness of occupations in the shipping industry partially contributes to the difficulty in retaining people to work at sea (Moreby 1975; Oldenburg et al. 2009; Haka et al. 2011). Other dimensions of industry's peculiarity are stress and fatigue which are induced by high workload, extensive paperwork and reduced crew levels. Zaar and Hammarstedt (2012) found that stress and fatigue also contribute to the difficulty in retaining young seafarers.

\section{The range of retention issues}

The 19 articles used in writing this paper cover a wide array of issues ranging from the training and recruitment of seafarers, onboard conditions, succession planning, cadetship, work-life balance among seafarers and the factors negatively and positively affecting retention of ship officers onboard. Table 1 shows the various papers and issues that they respectively cover. The 19 papers address the issue of shortage of seafarers in the global shipping industry but from different perspectives, showing the multidimensional aspect of the problem. 
Table 1 Papers and themes

Author

Forsyth 1990; Caesar et al. 2013; Fei 2013; Thomas et al. 2003; Thai et al. 2013

Gould 2010; Gekara 2008, 2009; Wild 2012

De Silva et al. 2011; Eler et al. 2009; Zaar and Hammarstedt 2012; Shiptalk 2008; Shantanu 2010

Oldenburg et al. 2013; Couper 2000; Haka et al. 2011; Zhao and Amante 2005; Kronberg 2011
Themes and issues

These papers focus mainly on the retention of ship officers. Primarily, factors such as working hours, rotation systems and holidays are all important components of the psychological contract for seafarers. When these factors are not properly managed, it leads to early exiting of seafarers. Also, issues such as the separation from family, shipboard and marital status may negatively influence satisfaction of seafarers which may then lead to attrition to landside jobs. The lack of work-life bal ance, stress and spending long time away from home negatively impacts on decisions of seafarers to pursue other landside opportunities.

All these papers cover cadetship among seafarers. Although the studies were primarily conducted in the UK, they essentially highlight the important aspects of the cadet programme among seafarers. Specifically, the challenges faced by cadets at sea are explored. A relationship is shown between the identified challenges and the attrition from ships to landside careers. For instance, the negative experiences of cadets with superiors onboard and difficulties in learning eventually lead to their movement from ships to pursue landside jobs. Other issues connected to high rate of attrition among cadets are as follows: physical confinement, restricted diet, distanced from family and unsupportive attitudes and hostility from mentors onboard.

These papers demonstrate that training is a very important aspect of the career life of seafarers. However, issues such as inadequate commitment to training programmes on the part of shipowners and lack of multiple career opportunities could force ship officers to move to landside jobs.

Motivating seafarers is necessary for their continued stay at sea. These papers identify the main motivators and demotivators of seafarers. The major demotivators are the following: spending a long time away from home and family, problems posed by cultural differences, isolation or loneliness among officers. Others are as follows: poor human resource practices (such as the ill treatment of seafarers due to unfair contracts, desertion from shipowners and salary arrears, lack of shore leave, inability to contact families at home from sea, highly pressurised working conditions and the additional workload instigated by the emergence of numerous international regulations) among shipping industry employers.

Like many other business sectors, retention is a major issue within the shipping industry. Although it is a problem that has been realised and discussed since the 1970s and 1980s (see for example, Moreby 1975; Walton et al. 1987), not much has been 
offered by way of a solution in the recent decades. The retention of maritime expertise, particularly within the offshore sector of the shipping industry, is an increasing challenge for industry employers. This has created a shortage of ship officers, especially for the deep-sea (blue water) segment (BIMCO/ISF 2010) of the shipping industry. Although multiple works have been published in relation to the retention of ship officers (Haka et al. 2011; Fei 2013; Thai et al. 2013), there is a paucity of studies on how the factors negatively impact on the retention of ship officers and influence the number of years they spend at sea. More importantly, there is a need for a greater understanding of the range of retention issues in order to prolong the number of years that ship officers spend onboard ships. Thus, this systematic review of the literature was undertaken to identify and examine factors that contribute to the reduction in years spent at sea by officers. Findings from this review are highly relevant towards addressing the complex range of issues making the retention of ship officers difficult and help to alleviate the aforementioned global shortage of ship officers.

The environment within which seafarers primarily work is constantly changing. These changes have both positive and negative aspects. With regard to the retention of ship officers, some of the issues emerging in relation to the working life of seafarers at sea could potentially predict whether they may stay onboard or move to landside jobs. Whereas some of the issues discussed are inevitable, shipping industry employers do have control over most and could therefore address them to improve the retention of ship officers within the global shipping industry.

\subsection{Criminalisation of seafarers}

One of the key issues connected to the working life of the modern-day seafarer is criminalisation. The criminalisation of seafarers is a very important issue within international shipping circles due to the negative impact on the recruitment and retention of ship officers. In recent times, there have been many unlawful arrests of seafarers (Kirby 2011, 2012). Mitroussi (2008) found that by criminalising unintentional marine pollution, the industry runs the risk of exposing seafarers to media criticism as well as discouraging disclosure of needed feedback regarding accidents in order to prevent their occurrence. In addition, research suggests that criminalising seafarers will instead lead to negative repercussions for image and safety (Dekker 2003, 2011). Couper (2012) explains that seafarers who experience neglect from their employers during periods of maritime pollution are vulnerable to both the media and the general public.

Many cases of neglect and eventual imprisonment of ship officers have been recorded within the literature (see for example, Gold 2004; ISF 2010). In a compilation of the ten major maritime pollution cases recorded between 1989 and 2012 within the global shipping industry, the literature (Gold 2004; ISF 2010; Seafarer 2011) summarises that in all ten cases, the ship masters were arrested and imprisoned for an average of 7.5 months before release. Others spent 18 months in gaol with the most recent sentence in the Costa Concordia's case being 34 months (ABC 2013). In some cases, the seafarers were not released and had their licence temporarily suspended. There are also cases where the entire crew were neglected and detained. Neglect from employers could probably be due to increased crewing costs (due to criminal sanctions and insurance) associated with the criminalisation 
of seafarers (Mitroussi 2008; Martin 2011). Also, the lack of a genuine link between shipowners and seafarers due to the prevailing involvement of manning companies in the hiring process could trigger neglect from shipping companies when seafarers are arrested.

The criminalisation of ship officers could potentially undermine efforts aimed at retaining seafarers. Peachey (2007) explains that criminalisation creates a syndrome of fear and caution among lower ranking seafarers which leads to negative repercussions for retention. Since criminalisation negatively impacts on the morale (Joshi 2005; Mitroussi 2008; Kirby 2012) of all categories of seafarers (such as cadets, junior and senior officers), it could be a critical factor in making decisions related to staying to work onboard or moving to a landside job.

\subsection{Serving time and challenges of cadets}

According to the STCW-95 and the 2010 Manila Amendments (Yabuki 2011), the training and transfer of skills for seafarers are deemed inadequate until the completion of 12/6 months compulsory onboard training (Bonnin et al. 2004). However, the onboard aspect of seafarer training is not bereft of challenges which negatively impacts on efforts aimed at improving retention at sea. In Gould (2010, p. 280), the experiences of cadet officers onboard ships are described in the following phrases, "Physical confinement, restricted diet, distanced from family and unsupportive attitudes and hostility from mentors onboard". These experiences largely contribute to cadet attrition (Gekara 2008, 2009) as it is in direct opposition to their expectations-leading to a breaking of the psychological contract (Caesar et al. 2013). Also, some cadets find working and living conditions at sea unbearable hence their eventual withdrawal from training programmes prematurely (Gekara 2010). In some countries, the plight of cadets with regard to securing onboard training starts with difficulty in finding shipowners or crewing agents willing to accept them. For example, Zhao and Amante (2005) found that first-time cadets in the Philippines could spend up to 13 months in search of their maiden job with a ship.

Zhao and Amante (2005) reported that cadets and redundant seafarers in the Philippines and China, respectively, undergo a lot of inhumane treatment as well as exploitation at the hands of crewing agencies, and in the case of the Philippines, mostly at the Rizal Park in Manila in order to secure onboard jobs. Findings from Turkey also revealed that many aspiring seafarers are exploited by extremely influential crewing companies (called Simsars) in the process of searching for jobs onboard ships (Parlak and Yildirim 2011). Thus, the twofold trend is that people (cadets and other seafarers) find it difficult to secure jobs onboard ships and also face many challenges onboard after securing the job. These circumstances may significantly contribute to the decision of seafarers leaving their jobs at sea to pursue landside opportunities.

\subsection{Industry regulations versus seafarer welfare}

Regulations are part of the seafaring culture (Couper 2012). In recent times, the shipping industry has been witnessing an unprecedented flurry of regulations and 
conventions (Shantanu 2010). Although regulations have a positive aspect (Graham 2009; Suppiah 2009b), their increased presence within the shipping industry negatively impacts on the welfare of seafarers (Mukherjee and Mustafar 2005) and consequently their retention onboard ships. For instance, regulations related to maritime security were found to exacerbate isolation among seafarers (Graham 2009). In particular, post 9/11 security regulations make it difficult for seafarers to take shore leave, especially in the US ports (Kahveci 2007). Thus, many of the regulations may eventually serve as a hindrance to seafaring careers as they negatively impact on crew welfare (Mack 2007). An increase in movement to landside jobs among seafarers could be indicative of falling welfare standards onboard which may need further investigation.

Another issue with increased regulations is that it has swelled the volume of administrative work onboard (Suppiah 2009a) for ship officers who have to comply with the many international maritime conventions. This was found to greatly demotivate ship officers and lead to their eventual exit, as increased workload breeds fatigue and fear of being penalised if the rules are inadvertently flouted (Bhattacharya 2009; Knudsen 2009; Haka et al. 2011). Furthermore, Cremers (2010) explains that too much paperwork may be inimical to the retention of young seafarers to whom ship officers sometimes delegate clerical tasks.

\subsection{Shipboard technology and reduced crew size}

Technology has been instrumental in the development of society, with specific evidence also found within the shipping industry (Winchester 2005). For economic reasons (see for example, Marlow and Mitroussi 2012; McLaughlin 2012; Silos et al. 2012), many shipowners are reducing the size of crew onboard their ships, and shipboard technology is playing a greater role in that regard (Bloor et al. 2000; Grey 2003). Oldenburg and Jensen (2012) show how crew size has been reduced from 30 to 24 onboard container vessels, with some owners being only prevented by maintenance tasks and not regulations, from reducing their crew to 14 .

Couper (2000) argues that using technology to reduce the size of a ship's crew leads to low morale among seafarers. A more credible explanation for this argument is that increased shipboard automation (especially in the engine room and on the bridge) has led to a rather monotonous work schedule for seafarers (Cahoon and Haugstetter 2008). Such a working routine breeds boredom which leads to a loss of job satisfaction for seafarers (Branch 2007). This then undermines efforts aimed at improving their retention and may translate into a decision to quit working onboard to pursue landside opportunities.

\subsection{Workplace health and safety issues onboard ships}

Workplace health and safety issues also constitute another important factor in the working life of seafarers, and there are many concerns in this regard that could influence their movement to landside jobs (Oldenburg et al. 2013). Concerns regarding the health of seafarers have long been an issue, and the ship has remained one of the most dangerous workplaces (Sampson and Thomas 2003; Jaremin et al. 2006). Consequently, seafaring is regarded as one of the most hazardous occupations in the world (Oldenburg and Jensen 2012), with suboptimal labour conditions (Bauer 2008), 
especially on Flag of Convenience (FOC) vessels where insufficient compensation constitutes one of the various forms of seafarer rights abuse (Bloor et al. 2000; MarineInsight 2011). Seafaring is an occupation that has always been associated with high risks due to shore and shipboard exposure (Bloor et al. 2000). An example can be cited of the exposure of seafarers to vessel engine room sound and vibrations as well as noise created by direct and indirect shipboard operations (Oldenburg and Jensen 2012). Such exposures result in disruption of the rest period of seafarers onboard and aggravate fatigue with associated health ramifications (Kaerlev et al. (2008). A thorough understanding of the sources of health hazards among seafarers is needed if shipping industry employers are to introduce measures to effectively address healthrelated concerns that departing seafarers may raise as their reasons for moving from sea to shore.

Pressure from tight and long hours of working schedules has become a common feature in the operation of modern vessels (Suppiah 2009b) with its attendant erratic sleep pattern among seafarers. This leads to disruption of the circadian rhythm (Spurgeon and Harrington 2001) which may have health implications for seafarers or increase the likelihood of accidents and onboard injuries (Wadsworth et al. 2008). Thus, the shift work system operated onboard ships results in a physiological conflict between sleeping or waking (Miller and Nguyen 2003). It means that while seafarers are working at night, their biological rhythm of their body may be demanding rest. All the foregoing conditions discussed could be a source of concern to serving seafarers and possibly influence their decision to move to landside jobs.

\subsection{The scourge of piracy}

Piracy is among the numerous challenges confronting the shipping industry. It is a thorny issue that is of key concern for seafarers, their families and the international maritime community (Mitropoulos 2011). It is also a major source of health risks among seafarers (Jeżewska and Iversen 2012). Koh (2012) concludes that piracy discourages existing seafarers from continuing a career in seafaring. Piracy could therefore be one of the potential predictors of high ship-to-shore mobility among seafarers.

\section{Strategies}

In the general human resource literature, 12 key factors are identified as being central to the retention of staff in organisations (Hausknecht et al. 2009). Although shipping industry employers tend to implement several strategies to address ship officer attrition and to improve retention (Wiseman 2004; Bajpaee 2005; Holder 2005), the impact made is quite insignificant due to many gaps and inadequacies. As presented in Fig. 3, the retention strategies of shipping industry employers are limited in a number of ways when compared to other industries. There is therefore a need for refocusing. The efforts of shipping industry employers need to be directed towards improving the working conditions of seafarers onboard at sea and refining existing hiring policies that do not favour seafarers from certain ethnic backgrounds. There is also a need to improve the relationship between shipping companies and seafarers. 


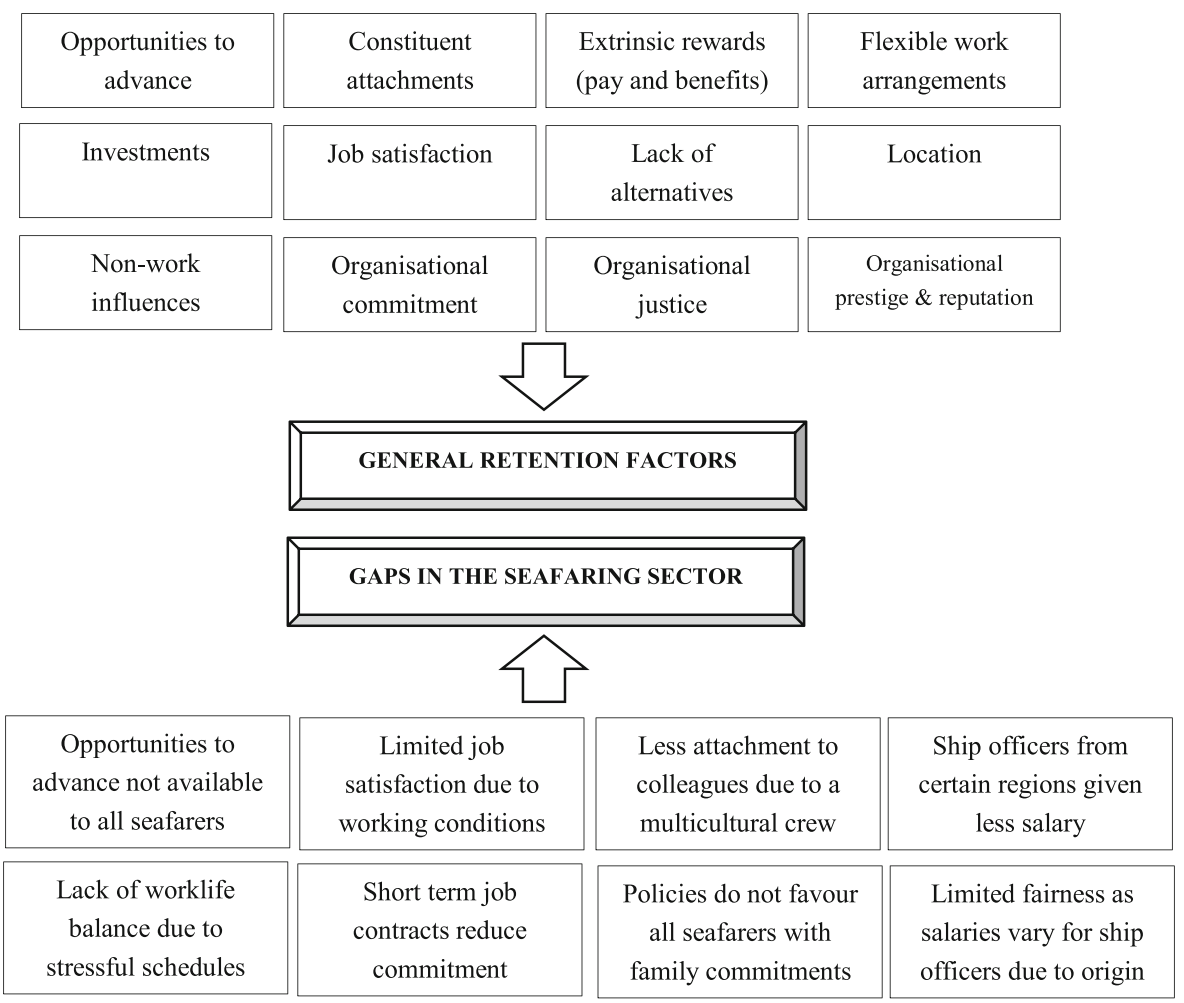

Fig. 3 Gaps in retention strategies of shipping industry employers

\section{Conclusions}

Improving the retention of seafarers requires multiple approaches. Several propositions have emerged from the existing literature as measures that labour stakeholders within the shipping industry can employ to specifically address the problem of high mobility among ship officers and improve retention of seafarers in general. The most common ones include as follows: improving welfare and working conditions, funding of training and skill development as well as mapping out a longterm career plan for seafarers (Watchkeeper 2003; Wiseman 2004; Bajpaee 2005; Holder 2005; Horck 2005). According to Nigel (2008), the provision of attractive remuneration and adequate motivation is used by some ship management companies in a bid to improve retention among crew (Mitroussi and Notteboom 2012). Studies have however confirmed that organisations cannot rely on monetary rewards alone to achieve the desired level of retention among staff; it is practically inadequate in the face of growing complexities. This is even truer for shipping, an industry with peculiar realities.

The following propositions (given in Fig. 4) are suggested from both the academic and practical perspectives towards an improvement in the retention of seafarers. From an industry perspective, it is important that measures used for both the hiring and retention of seafarers must focus on motivating seafarers to stay longer at sea as well as improve the working conditions onboard ships. Also crew welfare needs to be 


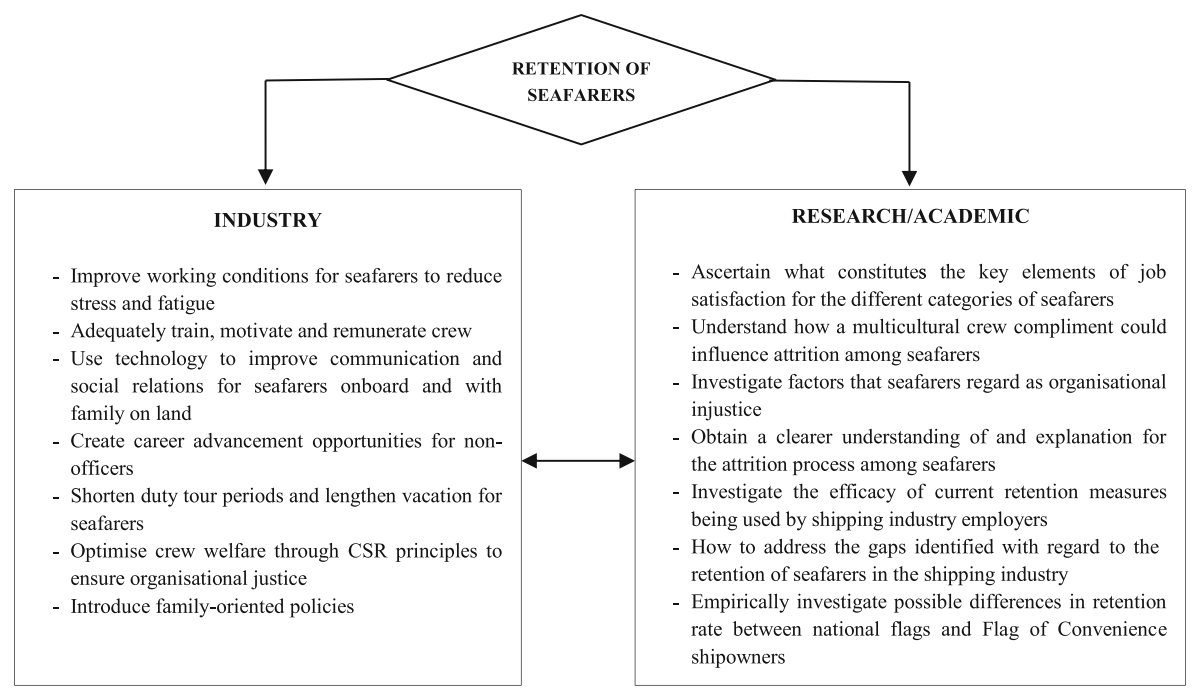

Fig. 4 Measures to improve retention of seafarers

improved through the refinement of organisational policies that are discriminatory towards seafarers. Furthermore, better management of the relationship between shipowners and seafarers is needed to improve retention.

Unfavourable working conditions onboard ships have led to dwindling interest in the seafaring profession among inhabitants of OECD countries as it is negatively affecting the attraction and recruitment of young people into the seafaring career. To attract young people into the maritime industry, there is a need for improvement in working conditions onboard ships in order to meet the expectations of the current generation of jobseekers. This should practically focus on the following areas: reducing long duty periods at sea and proportionately matching it with vacation periods without resorting to reduced salary, improving internet access, improving accommodation onboard, encouraging and increasing female presence onboard ships as well enhancing job security through improved social security initiatives. Working conditions at sea onboard ships may conflict with the expectations of seafarers and reasons why people take up a career in seafaring. Thus, shipping industry employers need to know the kind of people they are recruiting in order to effectively manage their expectations, and this requires a thorough understanding of the reasons and factors influencing people to enter into seafaring. Thus, improving working conditions onboard ships is essentially paramount for the retention of ship officers at sea.

To further obtain a clearer understanding of how the identified factors individually and collectively impact on the movement of seafarers from ships to landside jobs, future research must be aimed collecting empirical data on the predictive power of the identified factors through a web-based survey of seafarers. Given that seafarers are usually working far away from home, mail surveys may not be effective as web-based survey since most of them are now able to access internet connections onboard ship. Furthermore, industry interviews could be conducted for managers of seafarers to collect qualitative data to help articulate the range of retention issues and adequately explain the attrition process among seafarers. 


\section{References}

ABC, N (2013) Costa Concordia disaster: five jailed, Captain Schettino still on trial [Online]. Canberra: Australian Broadcasting Corporation. http://www.abc.net.au/news/2013-07-20/five-jailed-over-costaconcordia-disaster/4833148. Accessed 10 Dec 2013

Bajpaee R (2005) Seafarer shortages. Connecticut Maritime Association Shipping Conference, Stamford, Connecticut, 21-23 March 2005

Barnett M, Gatfield D, Overgaard B, Pekcan C, Graveson A (2006) Barriers to progress or windows of opportunity? A study in career path mapping in the maritime industries. WMU J Marit Aff 5(2):127-142

Bauer PJ (2008) The Maritime Labour Convention: an adequate guarantee of seafarer rights, or an impediment to true reforms? Chic J Int Law 8(2):643-659

Bhattacharya S (2009) The impact of the ISM code on the management of occupational health and safety in the maritime industry. $\mathrm{PhD}$, Cardiff University

BIMCO/ISF (2005) BIMCO/ISF 2005 manpower update - the world-wide demand for and supply of seafarers, University of Warwick: Institute for Employment Research

BIMCO/ISF (2010) BIMCO/ISF manpower update: the worldwide demand for and supply of seafarers. Dalian Maritime University and Institute for Employment Research, University of Warwick

Bloor M, Thomas M, Lane T (2000) Health risks in the global shipping industry: an overview. Health Risk Soc 2(3):329-340

Bonnin D, Lane T, Ruggunan S, Wood G (2004) Training and development in the maritime industry: the case of South Africa. Hum Resour Dev Int 7(1):7-22

Bos W, Tarnai C (1999) Content analysis in empirical social research. Int J Educ Res 31(8):659-671

Branch AE (2007) Elements of shipping. Routledge, United Kingdom

Caesar DL, Cahoon S, Fei J (2013) Breaking the psychological contract and managing expectations: developing solutions for the shortage of ship officers. 2013 International Association of Maritime Economists Conference, Marseille, France, 3-5 July 2013, pp 1-18

Cahoon S, Haugstetter H (2008) Shipping, shortages and generation Y. 8th International Conference on Maritime Training, Communication and Technology (MARTECH), Singapore, 13-14 October 2008, p 9

Cahoon S, Caesar DL, Fei J (2014) Human resource practices in seafaring: opportunities for improving retention. In: $\mathrm{Xu} \mathrm{J}$ (ed) Contemporary marine and maritime policy, vol 1, Business economics in a rapidly-changing world. Nova, New York, pp 85-103

Couper A (2000) Implications of maritime globalization for the crews of merchant ships. J Marit Res 2(1):1-8

Couper A (2012) Perceptions and attitudes of seafarers towards maritime regulations: an historical perspective. In: Chircop A, Letalik N, McDorman TL, Rolston S (eds) The regulation of international shipping: international and comparative perspectives: essays in honour of Edgar Gold. Martinus Nijhoff Publishers, Leiden, pp 429-442

Cremers P (2010) How to attract entrants to shipping industries: introduction of an actual experience by shipping industries. Seminar on the Problem of the Global Shortage of Seafarers and the role of the Shipping Industry through CSR activities, London, pp 171-180

De Silva R, Stanton P, Stanton J (2011) Determinants of Indian sub-continent officer-seafarer retention in the shipping industry. Marit Policy Manag 38(6):633-644

Dekker S (2003) When human error becomes a crime. Hum Factors Aerosp Saf 3(1):83-92

Dekker S (2011) The criminalisation of human error in aviation and healthcare: a review. Saf Sci 49(2):121127

Dimitrova DN, Blanpain R (2010) Seafarers' rights in the globalized maritime industry. Kluwer Law International BV, Netherlands

Eler G, Calambuhay J, Bernas L, Magramo M (2009) Officers' shortage: viewpoints from stakeholders. Int J Mar Navig Saf Sea Transp 3(4):471-474

Elo S, Kyngäs H (2008) The qualitative content analysis process. J Adv Nurs 62(1):107-115

Fei J (2013) Knowledge management in the shipping industry. Lap Lambert, Germany

Forsyth CJ (1990) Factors influencing job satisfaction among merchant seamen. Marit Policy Manag 17(2): 141-146

Forsyth CJ, Gramling R (1990) Adaptive familial strategies among merchant seamen. J Fam Econ Iss 11(2): $183-198$

Gekara VO (2008) Globalisation, state strategies and the shipping labour market: the UK's response to declining seafaring skills. PhD, Cardiff University

Gekara VO (2009) Understanding attrition in UK maritime education and training. Glob Soc Educ 7(2): 217-232 
Gekara VO (2010) The stamp of neoliberalism on the UK tonnage tax and the implications for British seafaring. Mar Policy 34(3):487-494

Gold E (2004) From privilege to peril. WMU J Marit Aff 3(1):51-66

Gould EA (2010) Towards a total occupation: a study of UK merchant navy officer cadetship. Doctorate PhD, Cardiff University

Graham CAE (2009) Maritime security and seafarers' welfare: towards harmonization. WMU J Marit Aff $8(1): 71-87$

Grey M (2003) The "image" of the shipping industry. WMU J Marit Aff 2(1):1-3

Haka M, Borch DF, Jensen C, Leppin A (2011) Should I stay or should I go? Motivational profiles of Danish seafaring officers and non-officers. Int Mar Health 63(1):20-30

Hart C (2012) Factors associated with student persistence in an online program of study: a review of the literature. J Interact Online Learn 11(1):19-42

Hausknecht JP, Rodda J, Howard MJ (2009) Targeted employee retention: performance-based and job-related differences in reported reasons for staying. Hum Resour Manag 48(2):269-288

Herzberg F, Mausner B, Snyderman BB (1993) The motivation to work. Transaction Publishers, New Jersey

Hill J (1972) The seafaring career: a study of the forces affecting joining, serving and leaving the merchant navy. Centre for Applied Social Research, Tavistock Institute of Human Relations, London

Holder L (2005) Manning and recruiting. BIMCO/Sohmen Forum, London

Horck J (2005) Getting the best from multi-cultural manning. BIMCO Bull 100(4):28-36

Horck J (2010) The gender perspective in maritime education and training. WMU J Marit Aff 9(1):93-119

ISF (2010) The year of the seafarer [Online]. International Shipping Federation. http://www.marisec.org/ Marisec\%20YOT\%20Seafarer\%20LR.pdf. Accessed 31 Jul 2012

Iversen R (2011) The mental health of seafarers - good news and bad news. Ausmarine 34(2):5

Jaremin B, Kotulak E, Starnawska M, Tomaszunas S (2006) Causes and circumstances of deaths of Polish seafarers during sea voyages. J Travel Med 3(2):91-95

Jeżewska M, Iversen R (2012) Stress and fatigue at sea versus quality of life. Gdansk, 11 June 2012. II International Congress on Maritime, Tropical, and Hyperbaric Medicine. Int Mar Health 63(2):106-115

Joshi R (2005) End 'rogue crew' image says head of Teekay [Online]. UK: Lloyd's List. http://www.lloydslist. com/11/sector/regulation/article95442.ece. Accessed 8 Aug 2012

Kaerlev L, Jensen A, Nielsen PS, Olsen J, Hannerz H, Tuchsen F (2008) Hospital contacts for noise-related hearing loss among Danish seafarers and fishermen: a population-based cohort study. Noise Health 10(39):41-45

Kahveci E (2007) Port-based welfare services for seafarers. Seafarers International Research Centre (SIRC), Cardiff

Kirby SM (2011) The criminalization of seafarers involved in marine pollution incidents. Company of Master Mariners of Canada International Conference, Halifax, Nova Scotia

Kirby SM (2012) The continuing criminalization of seafarers: where to go from here? In: Chircop A, Letalik N, McDorman TL, Rolston S (eds) The regulation of international shipping: international and comparative perspectives: essays in honour of Edgar Gold. Martinus Nijhoff Publishers, Leiden, pp 443-464

Knudsen F (2009) Paperwork at the service of safety? Workers' reluctance against written procedures exemplified by the concept of 'seamanship'. Saf Sci 47(2):295-303

Koh PK (2012) Impact of piracy on seafarers and shipping companies. Bachelors Bachelors, University of Tasmania

Kohlbacher F (2006) The use of qualitative content analysis in case study research. Forum Qual Soc Res 7(1). http://www.qualitative-research.net/index.php/fqs/article/view/75/153

Krippendorff K (1980) Content analysis: an introduction to its methodology. Sage, Newbury Park

Kronberg I (2011) Employee satisfaction on cruise ships. GRIN Verlag, Norderstedt

Lane A (2002) Philippine seafarers: realities, opportunities and challenges. Filipino Seafarers' National Convention, Manila, Philippines, 27-28 September 2002

Lindgren N, Nilsson J (2012) Filipinos sailing on the seven seas - a qualitative study of Filipino seafarers working on international vessels. Bachelors Bachelor, University of Borås

Ljung M (2010) Function based manning and aspects of flexibility. WMU J Marit Aff 9(1):121-133

Mack K (2007) When seafaring is (or was) a calling: Norwegian seafarers' career experiences. Marit Policy Manag 34(4):347-358

MarineInsight (2011) 7 dangers of Flags of Convenience (FOC) to seafarers [Online]. MarineInsight. http:// www.marineinsight.com/misc/maritime-law/7-dangers-of-flags-of-convenience-foc-to-seafarers/. Accessed 16 Apr 2014

Marlow P, Mitroussi K (2012) Shipping taxation. In: Talley WK (ed) The Blackwell companion to maritime economics. Wiley-Blackwell, Oxford, pp 304-320 
Martin JMC (2011) The seafarers rights and P\&I coverage on the crew in the UK. Masters of Maritime Law Master of Maritime Law, Lund University

Mayring P (2004) Qualitative content analysis. In: Flick U, von Kardoff E, Steinke I (eds) A companion to qualitative research. Sage, London, pp 266-269

McLaughlin HL (2012) Seafarers and seafaring. In: Talley WK (ed) The Blackwell companion to maritime economics. Wiley-Blackwell, Oxford, pp 321-332

Miller NL, Nguyen J (2003) Working the nightshift on the USS John C. Stennis: implications for enhancing warfighter effectiveness. Second Humans Systems Integration Symposium, Vienna, Virginia, 23-24 June 2003

Mitropoulos EE (2011) The year of the seafarer and the impacts of piracy. WMU J Marit Aff 10(1):1-5

Mitroussi K (2008) Employment of seafarers in the EU context: challenges and opportunities. Mar Policy 32(6):1043-1049

Mitroussi K, Notteboom T (2012) Getting the work done: a comparative study of motivation needs and processes for seafarers and dock workers. Asian Round Table 2012 Conference (ALRT 2012), University of British Columbia (UBC), Vancouver, 14-15 June 2012, pp 1-28

Moreby DH (1975) The human element in shipping. Seatrade Publications, Colchester

Mukherjee PK, Mustafar AM (2005) The International Ship and Port Facility Security (ISPS) Code and human element issues. In: Mejia MQ (ed) Contemporary issues in maritime security: a selection of papers and presentations from the workshop-symposium on the practical implementation and critical evaluation of the ISPS Code, 11-15 August 2003 and the International Symposium on Contemporary Issues in Maritime Security 30th August -1st September 2004. WMU Publications, Malmo, pp 277-285

Nigel K (2008) Innovation needed to meet crew shortage. Mar Log 113(6):23-26

Obando-Rojas B, Gardner BM, Naim M (1999) A system dynamic analysis of officer manpower in the merchant marine. Marit Policy Manag 26(1):39-60

Oldenburg M, Jensen HJ (2012) Merchant seafaring: a changing and hazardous occupation. Occup Environ Med 69(6):132-148

Oldenburg M, Jensen H-J, Latza U, Baur X (2009) Seafaring stressors aboard merchant and passenger ships. Int J Public Health 54(2):96-105

Oldenburg M, Jensen H-J, Wegner R (2013) Burnout syndrome in seafarers in the merchant marine service. Int Arch Occup Environ Health 86(4):407-416

Parker TW, Hubinger LM, Green S, Sargaent L, Boyd B (1997) A survey of the health, stress and fatigue of Australian seafarers. Australian Maritime Safety Authority, Canberra

Parlak Z, Yildirim E (2011) Labour markets for and working conditions of Turkish seafarers: an exploratory investigation. İktisat Fakültesi Mecmuası 55(1):87-104

Peachey L (2007) London calling. Marit Risk Int 2(12):6-7

Pekcan C, Barnett M, Gatfield D (2003) A national survey of cadets. Warsash Maritime Centre, Warsash

Rochdale JDK (1970) Merchant marine; shipping; Great Britain. H.M. Stationery Office, London

Sampson H, Thomas M (2003) Lone researchers at sea: gender, risk and responsibility. Qual Res 3(2):165189

Seafarer R (2011) High profile cases [Online]. England: seafarers' rights international. http://www. seafarersrights.org/seafarers-subjects/seafarers-rights-and-the-criminal-law/high-profile-cases/. Accessed 8 Aug 2012

Shantanu P (2010) Shortage of seafarers: why we don't act prudently? WMU Sasakawa Fellows' Network Meeting, Colombo, Sri Lanka

Sherar MG (1973) Shipping out: a sociological study of American merchant seamen. Cornell Maritime Press, Cambridge

Shiptalk (2008) Life at sea survey 2007/8: seafarer attraction and retention. Shiptalk Publishing, Tyne and Wear

Silos J, Piniella F, Monedero J, Walliser J (2012) Trends in the global market for crews: a case study. Mar Policy 36(4):845-858

Spurgeon A, Harrington JM (2001) Shiftwork and health. In: Koh D, Seng CK, Jeyaratnam J (eds) Textbook of occupational medicine practice. World Scientific Publishing Company Incorporated, Singapore, pp 421-442

Stemler S (2001) An overview of content analysis. Pract Assess Res Eval 7(17):137-146

Suppiah R (2009a) International Ship and Port Facility Security (ISPS) code and crew welfare. Marit Aff J Natl Marit Found India 5(1):57-72

Suppiah R (2009b) ISPS and manning issues. WMU J Marit Aff 8(1):89-103

Thai VV, Balasubramanyam L, Yeoh KKL, Norsofiana S (2013) Revisiting the seafarer shortage problem: the case of Singapore. Marit Policy Manag 40(1):80-94 
Thomas M, Sampson H, Zhao M (2003) Finding a balance: companies, seafarers and family life. Marit Policy Manag 30(1):59-76

Wadsworth EJK, Allen PH, Mcnamara RL, Smith AP (2008) Fatigue and health in a seafaring population. Occup Med (Lond) 58(3):198-204

Walton RE, Allen C, Gaffney M (1987) Innovating to compete: lessons for diffusing and managing change in the workplace. Jossey-Bass, Inc., San Francisco

Watchkeeper (2003) Tackling wastage by improving retention. Baltic and International Maritime Council (BIMCO) Conference, Copenhagen, Denmark, 12 February 2003

Wild A (2012) Securing the future of Australian shipping through officer education and training. Bachelors Bachelors, University of Tasmania

Winchester N (2005) Global regulation of seafarer certification. Seafarers International Research Centre's Fourth International Symposium, Cardiff, July 2005, pp 7-27

Wiseman N (2004) Consolidating international maritime labour standards. Int Marit Hum Elem Bull 4(5):1-8

Wu B (2004) Segmentation of global labour market for seafarers: quantitative evidence. Seafarers International Research Centre, Cardiff

Yabuki H (2011) The 2010 Manila amendments to the STCW Convention. J Marit Res 1(1):11-17

Zaar S, Hammarstedt K (2012) Promotion campaigns in the maritime sector and the attitude of young people towards a career at sea. masters Masters, Chalmers University of Technology

Zhao M, Amante MSV (2005) Chinese and Filipino seafarers: a race to the top or the bottom? Mod Asian Stud 39(3):535-557 